\title{
Die funksie en waarde van agtergrondstudie van die Nuwe Testament
}

A B du Toit

\section{ABSTRACT}

Background study of the New Testament: its function and value

To be able to understand any normal linguistic utterance, information regarding the context within which it functions, is of decisive importance. For that reason every exegete of the New Testament has to develop a broad frame of reference regarding the Jewish and Graeco-Roman world within which the New Testament documents originated. In spite of various obstacles, our knowledge of that world has increased immensely over the last century. The exegete should, however, also carefully distinguish between textual world, which is a construct of the author, and real world. As illustration of the value of background knowledge Romans 13:1-7 is discussed. It seems that both anti-Roman tendencies in Palestine and dissatisfaction with the Roman taxation system led to Paul's admonitions in this passage. It is also shown how several details of the text become transparent in the light of background information. The danger inherent in accentuating background study at the cost of the text itself is also illustrated.

\section{FUNDERING VAN DIE FUNKSIE VAN AGTERGROND- STUDIE}

Geen normale taaluiting is konteksloos nie. Dit geld ook van die geskrifte van die Nuwe Testament. Alhoewel hierdie dokumente oor die diepste vrae van menswees handel, is hulle konkreet gewortel in die leefwêreld van die mense wat by hulle totstandkoming betrokke was. In werklikheid sou 'n mens die so pas gemaakte stelling moes wysig tot die volgende een: Juis omdat die Nuwe-Testamentiese dokumente oor die diepste vrae van menswees handel, is hulle konkreet in die destydse mens se leefwêreld gewortel. Hulle wil immers nie mense in 'n lugleegte aanspreek nie. Menswees is altyd menswees in situ, menswees in 'n bepaalde situasie.

Presies vanweë hierdie gekontekstualiseerdheid van kommunikasie is kennis van die situasie of konteks waarbinne 'n taaluiting geskied, noodsaaklik vir suksesvolle verstaan. Kom ons neem 'n sinnetjie soos die 
volgende: "Ek sal jou kry". Sonder kennis van die daadwerklike konteks waarbinne hierdie rits gestruktureerde taaltekens voorkom, kan ons oor sy bedoeling slegs spekuleer. Sou dit twee persone wees wat 'n afspraak met mekaar maak? Of ' $n$ ongeduldige slaper se dreigement teenoor 'n muskiet? Of 'n verliefde jongman wat gedetermineerd is om sy droommeisie se liefde te wen? Hierdie vrae is telkens 'n soeke na konteks. Ons sal eers die antwoord op hierdie vrae ken wanneer ons weet om watter konkrete situasie dit gaan. Dit is teks plus konteks wat kommunikasie geslaagd maak.

Ons sou wat hierbo gestel is, ook nog anders kon formuleer deur te sê dat suksesvolle kommunikasie tussen sender en ontvanger minstens 'n bepaalde hoeveelheid gedeelde kontekstuele kennis vereis. Ons sou ook nog kon sê: Daar is 'n bepaalde minimum gemeenskaplike verwysingsraamwerk nodig. Hoe minder gedeelde verwysingsraamwerk daar is, hoe moeiliker word die verstaansproses en hoe makliker onstaan misverstand of totale kommunikasie-ineenstorting. Dit is derhalwe dikwels nodig dat die sender deur middel van sy kommunikasie self aan 'n verwysingsraamwerk bou. So vind ons byvoorbeeld dat Paulus homself in sy brief aan die huisgemeentes van Rome, waar hy nog relatief onbekend was, veel breedvoeriger moet voorstel as aan die Korintiërs of die Galasiërs onder wie hy reeds gewerk het.

'n Besondere dilemma ontstaan wanneer 'n bepaalde dokument bestudeer moet word sonder voldoende eksterne inligting aangaande die konteks waarbinne geskrywe word. In daardie geval is die navorser daarop aangewese om ' $n$ situasie uit die spesifieke teks self te probeer ekstrapoleer. Hierdie soort prosedure heet in die vakliteratuur "mirrorreading". Die vraag ontstaan in hierdie geval: Wanneer dui bepaalde formulerings inderdaad op 'n eksterne situasie en wanneer nie? As Paulus byvoorbeeld in Romeine 6:1 vra: "Wat sal ons nou hiervan sê? Sal ons aanhou sonde doen dat die genade kan toeneem?", moet ons uit hierdie vrae konkludeer dat daar Christene in Rome was wat 'n libertinistiese standpunt toegedaan was? Of is hierdie retoriese vrae bloot deel van die logiese gang van Paulus se betoog? Hierdie is die soort probleem waarvoor 'n mens in die proses van "mirror-reading" telkens te staan kom. Spieëllees moet dus met die grootste omsigtigheid hanteer word".

Die begrip "konteks", soos dit hier gebruik word, kan in twee kategorieë verdeel word. Eerstens is daar die relatief kontinue sosiale milieu of leefwêreld waarin mense hulle bevind. Hier kan gedink word aan die breë, algemene sosiale konteks of leefwêreld van Grieke en Romeine, of van die Palestynse Jode; maar hierby moet ons ook insluit die kleiner, 
meer konkrete leefwêrelde soos dié in Atene of Jerusalem of in die Koemraangemeenskap. Tweedens is daar die duisendvoudige kontingente,, konkrete lewensituasies binne eersgenoemde leefwêrelde, soos Jesus se verhoor voor die Sanhedrin, Paulus in die tronk te Filippi en Johannes op die Patmos. Van albei hierdie kategorieë, naamlik leefwêreld sowel as konkrete lewensituasie, geld steeds: hoe meer gedeelde kennis daar tussen sender en ontvanger is, hoe makliker is geslaagde kommunikasie.

In agtergrondstudie gaan dit om die eerste kategorie. As ons vandag die Nuwe-Testamentiese tekste van twee duisend jaar gelede wil verstaan, moet ons gaan insit aan die kant van die destydse ontvangers. In ons poging om hierdie tekste te begryp moet een van ons belangrikste mikpunte wees om ons verwysingsraamwerk aangaande die wêreld van die Nuwe Testament sodanig uit te brei dat dit so na as moontlik sal kom aan dié waarmee 'n ingeligte destydse hoorder/leser daardie dokumente sou ontvang het. Die woord "mikpunt" word opsetlik gebruik, omdat dit hier steeds om 'n strewe gaan. Ten spyte van voortdurende vordering sal die daadwerklike verwesenliking van hierdie doelwit altyd buite ons bereik bly. Ook hier bly ons kennis steeds "ten dele". Hiervoor is daar veral vyf redes. Eerstens bestaan daar tussen vandag en twee duisend jaar gelede nie net 'n tydsgaping van twee millenia nie, maar ook 'n ontsaglike sosiokulturele kloof. Tweedens bestaan daar nog steeds groot leemtes in ons beskikbare bronnemateriaal. Voor die ontdekking van die Koemraangeskrifte sou ons byvoorbeeld veel minder geweet het van die gevarieerdheid van die Palestyns-Joodse wêreld. Hierdie leemtes in ons bronne is deels daaraan toe te skryf dat soveel argeologiese materiaal verlore gegaan het, deels daaraan dat bepaalde inligting nooit gedokumenteer is nie. Derdens begaan die geleerde wêreld soms ernstige foute ten opsigte van die bronne wat wel beskikbaar is. Hierdie foute word soms klakkeloos van die een geslag na die ander herhaal. So is die Joodse en die Grieks-Romeinse wêrelde vir baie lank as twee duidelik afgebakende, losvan-mekaar-staande eenhede beskou. Intensiewer bronnestudie moes ons egter leer dat hierdie siening 'n mite was. Vierdens was ons antieke tekste, soos alle tekste, die produk van interpretasie en outeursopset (veral die doelstelling om te beïnvloed). Wie byvoorbeeld, soos meermale gedoen word, die gegewens van Josefus op sigwaarde as objektiewe inligting hanteer, is baie naïef omdat hierdie sogenaamde historiese bron in werklikheid sterk ingekleur word deur outeursinterpretasie en retoriese strategieë. Vyfdens is ook ons vandag voortdurend op die interpretasie van bronne aangewese en is verskillende wetenskaplikes se vertolkings nie noodwendig dieselfde nie. So is die vroeë Joods-Palestynse godsdiens vir 
lank as 'n uiters wettiese vormgodsdiens geïnterpreteer. 'n Sterk groep wetenskaplikes onder leiding van E P Sanders meen vandag dat daardie interpretasie foutief was". Hulle skryf hierdie "mistasting" daaraan toe dat die vroeë Judaïsme deur 'n Luthers-Protestantse bril bekyk is. Die vraag is: Wie is reg? Of lê die antwoord straks tussen-in? En sesdens ontkom ons ook hier nie aan die probleem van "mirror-reading" nie.

Gemelde probleme beteken egter geensins dat ons agtergrondstudie moet afskryf nie. Die teenoorgestelde is eerder waar. In werklikheid is al geweldig baie bereik. Ons beskik vandag oor 'n breë kennisbasis wat deur geslagte besonder knap en toegewyde navorsers opgebou is en wat ons, tesame met meer verfynde eksegetiese metodes, in staat stel om die rykdom van die Nuwe-Testamentiese tekste veel beter as voorheen te ontgin. Een van die redes vir hierdie suksesverhaal was die interdissiplinêre samewerking tussen Nuwe-Testamentici, Ou-Testamentici, Semitici, argeoloë, klassici, sosioloë, godsdiens-historici en vele ander. Wanneer soveel wetenskaplikes van allerlei agtergronde en selfs owerheids-instansies by 'n saak betrokke is, ontstaan daar maklik belangebotsings, intriges en kleinlike eersoekery. Dit het ook in hierdie geval gebeur. Tog het die groot mate van samewerking en wetenskaplike openheid wat daar wel was, ons agtergrondkennis geweldig bevorder. Daarbenewens gaan die soektog na nuwe bronne, asook hulle ontsluiting, beskikbaarstelling en bestudering steeds voort. Telkens, selfs na soveel eeue, word ons met nuwe vondste gekonfronteer. Dink maar net aan die massas inskripsies en papiri wat vanaf die negentiende eeu tot ons beskikking gekom het; aan die epogmakende ontdekkings van die NagHammadi-biblioteek en veral die Koemraandokumente teen die helfte van die twintigste eeu. Watter ontsaglike invloed het hierdie ontdekkings nie op die stand van ons kennis en insig gehad nie. Agtergrondstudie is waarskynlik die vakgebied in die Bybelwetenskap waarop daar in die afgelope eeu die mees substansiële vordering gemaak is.

Die rol van die Nuwe Testament self ten opsigte van agtergrondstudie moet egter nie misgekyk word nie. Tussen die Nuwe-Testamentiese dokumente en hulle leefwêreld bestaan daar 'n wederkerige relasie. Aan die een kant werp agtergrondstudie, soos ons dit uit ander bronne rekonstrueer, lig op die verstaan van die Nuwe Testament. Aan die ander kant dra die Nuwe Testament self ook tot ons agtergrondkennis by.

Wanneer ons die nut van agtergrondstudie vir die verstaan van die Nuwe Testament evalueer, moet ons terselfdertyd begryp dat agtergrondkennis nie sonder sy gevare is nie. So kan ons vanuit 'n gebrekkige of foutiewe agtergrondkennis 'n Nuwe-Testamentiese teks heeltemal 
misverstaan, of ons kan ons agtergrondkennis wederregtelik op 'n Nuwe Testamentiese teks afforseer. Wie geruime tyd met agtergrondstudie besig is, weet hoe gretig wetenskaplikes en kwasi-wetenskaplikes is om vanuit nuutgewonne agtergrondkennis "nuwe lig" op 'n Bybelteks te werp. Dit gebeur byvoorbeeld maklik as mense, om begryplike redes, aspekte van die Bybel as "waar" probeer bewys. Hierdie "nuwe lig" word ongelukkig meermale 'n dwaallig omdat die hooggeroemde agtergrondinligting en die betrokke teks net eenvoudig nie op mekaar pas nie. As grondreël vir die legitieme aanwending van agtergrondkennis moet deurgaans geld dat die strekking van die teks self prioriteit moet geniet. Nuttige agtergrondinligting is inligting wat inpas in die beperkende seine wat die onderhawige teksnetwerk uitstuur. Enige aanwending van agtergrondinligting wat teen die interne beweging van die teks self ingaan, hoe verfrissend nuut of belangrik dit ook mag voorkom, moet afgewys word.

Om die problematiek waarom dit hier gaan, goed te begryp moet ons nog dieper op die verhouding tussen agtergrondkennis en ons lees van Nuwe-Testamentiese tekste ingaan: Teksteoreties moet ons onderskei tussen tekswêreld en werklike wêreld. Dit is onwetenskaplik om hierdie twee wêrelde as identies te beskou. Deur middel van taaltekens en -strategieë skep die outeur van 'n teks 'n spesifieke tekswêreld waaraan die implisiete outeur (die een binne die teks) en die implisiete lesers, in kombinasie met ander binne-tekstuele rolspelers, deelneem en help vormgee. Hierdie binne-tekstuele wêreld is 'n konstruk van die werklike skrywer waarmee hy, miskien meer intuïtief as bewustelik, die werklike wêreld op so 'n wyse aanbied dat sy doelstellings bevorder word. Die skrywer van die Johannesevangelie verklaar byvoorbeeld eksplisiet dat hy sy Jesusverhaal doelbewus so aangebied het dat hy sy lesers tot (meerdere) geloof kon lei (Joh 20:30-31).

Waar ons dus moet aanvaar dat daar nie 'n een tot een relasie tussen tekswêreld en werklike wêreld bestaan nie, impliseer dit dat die korrelasie tussen werklike leefwêreld en tekswêreld op 'n glyskaal kan wissel tussen nader aan (in die geval van informatiewe tekste) en verder van (in die geval van fiktiewe tekste) 'n een tot een verhouding. Selfs in laasgenoemde geval moet daar egter nog genoeg korrelasie bestaan om verstaanbare verwysing überhaupt moontlik te maak. Selfs die wolf in die Rooikappieverhaal, wat in soveel opsigte anders optree as 'n werklike wolf, besit nog sekere gemeenskaplike trekke met ' $n$ werklike wolf. Anders sou hy net sowel 'n leeu of 'n buffel kon heet.

Die Nuwe-Testamentiese dokumente is nie fiktiewe tekste nie. Alhoewel ons, vanweë die hierbo gemelde gesigspunt geensins met 'n een 
tot een relasie kan reken nie, bestaan daar wel so 'n mate van korrelasie tussen tekswêreld en werklike wêreld dat kennis van laasgenoemde 'n besonder verrykende lig op die verstaan van hierdie dokumente kan werp. Tog moet ons, soos reeds gesê, met die toepassing van agtergrondkennis op die Nuwe Testament versigtig te werk gaan en steeds die prioriteit van die teks self respekteer. Die Nuwe-Testamentiese tekste toon soms 'n tendens om die verwagtinge wat ons vanuit ons agtergrondkennis na 'n passasie toe bring, juis om te keer. So weet ons dat tollenaars in die destydse samelewing in ' $n$ groot mate as skurke gestigmatiseer was. Tog mak sekere Nuwe-Testamentiese tekste van hierdie "skurke" juis positiewe rolmodelle (Luk 18:9-14; Mat 21:31-32). Nog 'n voorbeeld: Uit ons kennis van destydse verhoudings tussen Jode en Samaritane sou ons verwag dat die Samaritaan van Lukas 10:30-37 nie alleen sonder meer by die slagoffer van die rowers sou verbygaan nie, maar hom ook nog oor laasgenoemde se lot sou verheug. Die teendeel gebeur egter. Hy tree juis a-tipies op. Dit is presies hierdie botsing tussen verwagting en narratiewe gebeure wat aan die gelykenis sy besondere trefkrag gee. Ons gaan vervolgens Romeine 13:1-7 aan die orde stel om die waarde, maar ook die gevaar van agtergrondstudie te illustreer.

\section{DIE WAARDE (EN GEVAAR) VAN AGTERGRONDSTUDIE GEILLUSTREER AAN DIE HAND VAN ROMEINE 13:1-7}

Waar ons vorige passasie in 'n Joods-Semitiese omgewing afspeel, is Romeine 13:1-7 in die Grieks-Romeinse leefwêreld tuis. By die eerste oogopslag lyk hierdie perikoop oor die verantwoordelikhede van Christene teenoor die Romeinse staat, na 'n corpus alienum in die Romeinebrief.

Die makrokonteks waarbinne 13:1-7 val, is 12:1-15:13. Die eerste elf hoofstukke van Romeine was diskursief van aard en het 'n sterk indikatiewe karakter besit. Dit het gegaan om die vryspraak wat God uit genade skenk aan hulle wat glo. Hoofstuk 12 markeer 'n duidelike wending. Van hier af oorheers die imperatiewe. Dit gaan nou om 'n oproep tot 'n gehoorsaamheidslewe in antwoord op God se ontferminge (12:1). Daarom is hierdie gedeelte geheel en al paraneties van aard. Na twee sterk, inleidende verse (12:1-2) volg in 12:3-8 'n passasie oor die regte gebruik van die genadegawes, waarop in 12:9-21 'n salvo staccatoagtige vermanings as ' $t$ ware op die lesers afgevuur word. Soos die NuweTestamentiese paranese in die algemeen, vertoon ook hierdie vermaninge nie so 'n sterk interne kohesie as die diskursiewe stof nie. Tog is hulle geensins sonder kohesie nie. Enersyds word hulle tematies daardeur 
verenig dat hulle almal oor die Christelike etos handel en onder die teken van die Christelike lewe as 'n geleefde offer (vgl 12:1-2) aan God staan; andersyds word hulle tog in 'n groot mate saamgebind deur die ondertoon van die Christelike liefde. Hoofstuk 13:8-14 sluit naatloos hierby aan, nie net wat die aard van sy paranese betref nie, maar ook ten opsigte van die liefdesmotief. Die enigste verskil is dat wat voorheen die ondertoon was, nou die botoon voer. Die vraag is hoe Romeine 13:1-7 binne hierdie konteks inpas. Wilckens ${ }^{3}$ en De Kruij ${ }^{4}$ is sterk van oortuiging dat hierdie passasie uitstekend in die konteks inpas. Michel daarenteen handhaaf die teenoorgestelde standpunt ${ }^{5}$. Op die oog af lyk dit of Michel reg is. Dit wil inderdaad voorkom of die sterk kontinuïteit tussen 12:9-21 en 13:8-14 deur 13:1-7 onderbreek word. Waar die voorafgaande en volgende gedeeltes redelik algemene paranese bevat, word hier 'n heel spesifieke tema ingevoer: die Christen se verantwoordelikheid teenoor die staat. Die terminologie is sterk administratief en staatsregtelik. In plaas van die liefde gaan dit hier om onderhorigheid. In plaas van eskatologiese verwagting gaan dit om lofbetuiging of bestraffing deur die staat. Waar die voorafgaande gedeelte in die tweede persoon aanspreekvorm geklee was, begin 13:1vv in die derde persoon. Daar is meer afstand, groter saaklikheid, meer beredenering, soos die sewe-malige voorkoms van $\gamma \dot{\alpha} \rho$ (vgl ook óó: v.5) duidelik aandui. Romeine 13:1-7 skep dus inderdaad die indruk van 'n outonome eenheid wat nie heeltemal vlot in sy huidige konteks inpas nie. Selfs 'n normaalweg behoudende eksegeet soos Ridderbos sê van hierdie gedeelte: "En er is méér reden te zeggen, dat zij in het verband is ingelast, dan dat zij daaruit als het ware organisch zou voortkomen"6. Dit is dan ook geen wonder dat Romeine 13:1-7 al dikwels as 'n later, nie-Pauliniese interpolasie bestempel is nie (o.a. Barnikol' Kallas $^{8}$, O'Neill', Schmithals ${ }^{10}$, Munro'11).

'n Eerste probleem met die nie-Pauliniese interpolasieteorie is egter dat daar geen tekskritiese getuienis vir so 'n vermoede bestaan nie. Al ons huidig-bestaande Griekse tekste bevat hierdie passasie. In so 'n geval is 'n interpolasieteorie altyd 'n verleentheidsoplossing, tensy oortuigend verklaar kan word hoe die betrokke tekswysiging op so 'n vroeë stadium van die teksoorlewering aangebring kon gewees het dat die nuwe, gewysigde teks in alle beskikbare kopieë gereflekteer word. Of anders sou 'n oortuigende rede gevind moes word vir die verdwyning van alle manuskripte wat wel 'n korter lesing bevat het.

'n Tweede probleem met die nie-Pauliniese interpolasiehipotese is dat ons in 13:1-7 talle tipies Pauliniese formulerings kry, soos Friedrich, Pöhlmann en Stuhlmacher tereg en uitvoerig aangetoon het ${ }^{12}$. In aansluiting 
by hulle ondersoek word net die volgende seleksie gemaak: Die werkwoord $\dot{v} \pi \varepsilon \rho \varepsilon \chi \chi \omega \mathrm{kom}$, behalwe in 1 Petrus $2: 13$, in die Nuwe Testament slegs by Paulus voor (Rom 13:1; Flp 2:3; 3:8; 4:7). Van die agt en dertig voorkomste van $\dot{v} \pi o \tau \dot{\alpha} \sigma \sigma \omega$ in die Nuwe Testament kry ons, afgesien van die twee in Romeine 13:1-7, nog veertien in die onomstrede en sewe in die omstrede Paulusbriewe. rò $\dot{\alpha} \gamma \alpha \theta o ́ \nu$ is 'n tipies Pauliniese uitdrukking wat, afgesien van die twee voorkomste in Romeine 13:3-4, nog twaalf keer in die onomstrede Paulusbriewe verskyn, een keer in Efesiërs en in die hele res van die Nuwe Testament slegs twee keer. Van die dertig

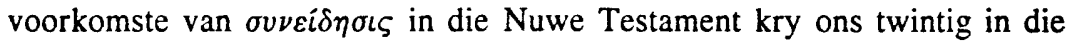
corpus Paulinum (waarvan veertien in die onomstrede briewe). Daarteenoor het Wilckens ${ }^{13}$ sowel as Friedrich ${ }^{14}$ en sy kollegas aangetoon dat ons in hierdie passasie slegs 'n beperkte aantal nie-Pauliniese woorde kry. Verskeie van hierdie terme kan egter verklaar word as afkomstig uit die tradisie wat Paulus hier opneem, sowel as uit die destydse administratiewe en staatsregtelike terminologie. In die lig van die woordgebruik van Romeine 13:1-7 het ons dus geen rede om hierdie passasie as on-Paulinies te beskou nie. Indien dit wel 'n interpolasie is, moes Paulus dit na alle waarskynlikheid self op 'n vroeë stadium, waarskynlik nog voor die versending van die brief, ingevoeg het.

Daar is egter nog 'n derde probleem, hierdie keer met die interpolasieteorie as sodanig: 'n Meer indringende ondersoek van die literêre konteks van Romeine 12:1-13:14 bring aan die lig dat 13:1-7 tog nie heeltemal so 'n losstaande eenheid binne sy makrostruktuur is nie (Wilckens ${ }^{15}$, Friedrich, Pöhlmann \& Stuhlmacher ${ }^{16}$, Bruce ${ }^{17}$ ). Eerstens kry ons 'n duidelike skakelwoord-verbinding tussen $\tau \grave{\alpha} \varsigma \dot{o} \phi \varepsilon \iota \lambda \dot{\alpha} \varsigma$ in 13:7 en $\dot{o} \phi \varepsilon i \hat{\lambda} \varepsilon \tau \varepsilon$ in 13:8. Die etiese kontraspaar "kwaad-goed" wat in 13:3-4 gebruik word, sluit aan by 12:(2),9,17,2118 en vind naklank in 13:10. Ook woorde soos $\dot{\varepsilon} \kappa \delta \iota \kappa \dot{\varepsilon} \omega / \check{\varepsilon} \kappa \delta \iota \kappa \circ \varsigma(12: 19 ; 13: 4)$ en $\dot{o} \rho \gamma \dot{\eta}(12: 19 ; 13: 4-5)$ en die universeelgerigte $\pi \dot{\alpha} \nu \tau \omega \nu \dot{\alpha} \nu \theta \rho \dot{\omega} \pi \omega \nu / \pi \hat{\alpha} \sigma \iota \nu(12: 17-18 ; 13: 7)$ lê 'n band tussen 13:1-7 en sy ruimer literêre konteks ${ }^{19}$. Nie al hierdie literêre argumente weeg ewe swaar nie. Sekere woordherhalings, veral die laasgenoemdes, kan bloot aan die aard van die onderwerp en Paulus se tipiese paranetiese styl toegeskryf word. Die oorkoepelende gewig van hierdie literêre argument moet egter nie onderskat word nie.

Op die dieperliggende, semantiese vlak moet nou egter ook nog op 'n belangrike saaklike verbinding tussen 12:3-21 en 13:1-7 gewys word. In die gedeelte oor die charismata in 12:3-8 en die eerste deel van die groep paranetiese opdragte in 12:9-21 gaan dit om die onderlinge optrede van Christene binne die Christelike gemeenskap. In 12:14 word die venster 
effens na die buitewêreld oopgestoot wanneer van vervolgers van die Christene gewag gemaak word, maar die fokus is tot in vers 16 nog na binne gekeer. Vanaf verse 17-20 verskuif die fokus egter heel duidelik na Christene se optrede in die wêreld daarbuite. Romeine 13:1-7 konsentreer op een besondere faset van daardie buitewêreld, naamlik die Christen se verantwoordelikheid teenoor die staat. Hierop volg 13:8-13 as 'n samevatting van die voorbeeldige wyse waarop Christene teenoor alle mense, gelowiges sowel as ongelowiges, behoort op te tree. Friedrich, Pöhlmann en Stuhlmacher ${ }^{20}$ meen dat die verswyging van Christene se politieke verantwoordelikheid 'n merkbare leemte in die Pauliniese paranese sou laat, veral as ons dit vergelyk met analoë paranetiese gedeeltes soos 1 Petrus 2:13-17, 1 Timoteus 2:1vv en Titus 3:1v waar Christene se politieke verantwoordelikheid deel van 'n breër paranese uitmaak. 'n Beswaar hierteen sou kon wees dat ons in geen ander paranetiese gedeelte in die Paulusbriewe weer 'n verwysing na die Christen se verpligtinge teenoor die staat kry nie. Afgesien van die problematiese wat gewoonlik aan 'n argumentum e silentio kleef, is hierdie beswaar egter in elk geval nie geldig nie, aangesien die voorafgaande Pauliniese vermanings, veral vanaf $12: 17$, reeds met die Christen se optrede in gevalle van opposisie en problematiese eksterne situasies te make het. Dit sou hierby heel logies inpas as Paulus nou sou oorgaan tot 'n ander eksterne probleemsitausie, naamlik die Christen se posisie binne die Romeinse staat.

Ons bevinding: Ons kan met sekerheid aanvaar dat Romeine 13:1-7 van Paulus afkomstig is en dus nie as 'n nie-Pauliniese interpolasie beskou kan word nie. Verder kan ons op grond van literêre sowel as saaklike oorwegings met 'n hoë mate van waarskynlikheid aanvaar dat hierdie gedeelte van die begin af ' $n$ integrale gedeelte van die Romeinebrief uitgemaak het. As dit alles gesê is, kan ons egter nie die moontlikheid heeltemal uitsluit dat Paulus hom na voltooiïng van sy brief, maar voor versending saam met Febe, genoodsaak gevoel het om 'n aantal dringende opmerkings oor Christene se verantwoordelikheid teenoor die Romeinse staat by te voeg nie. In daardie geval sou die mees aangewese plek dié tussen 12:21 en 13:8 gewees het en sou die aanhaak-verbinding tussen 13:7 en 13:8 ad hoc geskep gewees het. Die ander literêre verbindingslyne sou dan aan die tipe stof en Paulus se kenmerkende styl toegeskryf kon word.

Die hierbo aangevoerde argumente ten gunste van Romeine 13:1-7 as 'n integrale gedeelte van die Romeinebrief verklaar egter nog nie sekere uiters belangrike inhoudelike aspekte van hierdie gedeelte nie: waarom Paulus hier so breed uitwei oor die staat; waarom hy soveel motiverings 
gee (vgl die sewemalige $\gamma \alpha \dot{\alpha} \rho$ en die $\delta$ ió); waarom hy Christene se plig tot onderdanigheid en eerbetoon so sterk beklemtoon en ten slotte waarom die noodsaaklikheid van die betaling van belasting en aksyns so spesifiek aan die einde beklemtoon word. Die vir ons doel so belangrike vraag is nou: Kan hiervoor 'n sinvolle verklaring gevind word? En straks ook vir die moontlikheid dat Paulus dit noodsaaklik sou kon gevind het om hierdie gedeelte dringend agterna in te werk? Dit plaas die vraag na die destydse tydhistoriese omstandighede voluit op ons tafel.

Käsemann ${ }^{21}$ het die aanleiding tot Romeine 13:1-7 gesoek in interne gemeentelike omstandighede onder die Romeinse Christene. Sy standpunt was dat Paulus hierdie woorde rig teen 'n groep geesdrywers. Hierdie mense was so hemelgerig dat 'n "aardse" saak soos belastingbetaling vir hulle heeltemal irrelevant voorgekom het. Die beswaar teen Käsemann se teorie is dat ons geen bewyse vir so 'n geesdrywende front in Rome het nie. Wanneer ons byvoorbeeld na die geestesgawes in 12:3-8 kyk, is die profesie, anders as in die geval van Korinte, die enigste geestesuiting wat miskien onder die "entoesiastiese" charismata geplaas sou kon word. Dit is egter foutief om die situasie in Korinte op die huisgemeentes in Rome te projekteer.

Die vraag is of die politieke omstandighede van destyds ons nie nader aan 'n oplossing kan bring nie. Georg Strecker ${ }^{22}$ was van mening dat dit onmoontlik is om so 'n politieke verklaring te vind. Ons hoef hom egter nie sonder meer gelyk te gee nie. Nuwe insigte kan ons in hierdie verband tog verder help.

Verskeie navorsers het oor die afgelope sowat dertig jaar navorsing oor die tydhistoriese konteks van Romeine 13:1-7 gedoen. Die baanbrekerswerk van veral Strobel, Van Unnik, Borg. Haacker, Friedrich, Pöhlmann en Stuhlmacher (die laaste drie gesamentlik) moet in hierdie verband genoem word. Die bydrae van hierdie werke lê op twee gebiede: Eerstens is kosbare inligting ingebring ten opsigte van die beter verstaan van die inhoud van hierdie passasie en tweedens is belangwekkende navorsing gedoen ten opsigte van die konkrete aanleiding tot die skryf daarvan. Ons stel laasgenoemde saak eerste aan die orde.

Die eerste persoon wat 'n omvattende rydhistoriese verklaring vir die ontstaan van Romeine 13:1-7 probeer gee het, was Marcus Borg. Sy basiese argument is dat daar reeds in $56 \mathrm{nC}$ (toe Paulus sy Romeinebrief skrywe) by die Christelike gemeenskap in Rome, wat sterk onder Joodse beïnloeding verkeer het, groot simpatie moes bestaan het vir die groeiende Joods-nasionale, anti-Romeinse Selotiese tendens in Palestina wat uiteindelik op die tragiese Joodse Oorlog van 66-70 nC uitgeloop het. 
Borg se standpunte is soms eensydig en hy kom te maklik tot gevolgtrekkings. So aanvaar hy byvoorbeeld dat die Chrestos waarvan Suetonius in Claudius 25:4 skrywe en op grond van wie se optrede die Jode Rome moes verlaat, 'n daadwerklike Joods-messiaanse agitator in Rome was. Voorts kom hy tot die gevolgtrekking dat dit in Jesus se gebod tot vyandsliefde en in Paulus se opdragte in Romeine 12:14,17-21 spesifiek om die liefde tot die Romeinse vyand gegaan het. Tog kan daar min twyfel bestaan dat sy opmerkings ten opsigte van Romeine 13 'n element van waarheid bevat. Die lewendige kontak tussen Jode oor die Romeinse ryk heen kan nie ontken word nie. Dit is haas ondenkbaar dat die groot getal Jode in Rome (Borg plaas hulle saam met H J Leon ${ }^{23}$ op 50 000) nie simpatiek sou gestaan het teenoor hulle volksgenote in Palestina wat steeds na politieke onafhanklikheid gesmag en allerlei wreedhede van Romeinse bewindhebbers moes deurmaak nie. Die anti-Romeinse uitbarstings in Palestina gedurende die tyd van Kumanus (48-52 nC) en Feliks (52-60) wat so bloedig en wreed onderdruk is, sou sekerlik nie op onsimpatieke ore in Rome geval het nie. Daarby weet ons dat die Jode in Rome telkens onder Romeinse keisers gely het: In $19 \mathrm{nC}$ het Tiberius hulle uit Rome verdrywe; vir twaalf jaar het hy Sejanus toegelaat om 'n anti-Joodse beleid te volg; die onstabiele Kaligula het die Jode gehaat; Klaudius het die Jode in 49 nC uit Rome verban. Hierdie dinge moes 'n merk op die Joodse gemoed in Rome gelaat het en kon ook weerklank onder die Christene in Rome gevind het. Uiteraard kon daar in Rome geen sprake wees van 'n suksesvolle opstand teen die owerheid nie. Ons kan egter met goeie gronde vermoed dat die antipatie teen die Romeinse owerheid wel in mense se houding moes deurgeskemer het. Hierdie antipatie kon konkreet in 'n traagheid om belastings te betaal na vore begin tree het.

Dit is ietwat verrassend dat Borg nie aan hierdie laaste aspek, wat juis die konkrete toespitsing van Paulus se paranese in Romeine 13:1-7 uitmaak, aandag gee nie. Die anti-Romeinse reaksie onder Palestynse Jode was van die begin af aan die belastingkwessie gekoppel. Dit was reeds die geval met die opstand van Judas die Galileër in $6 \mathrm{nC}^{24}$. Alhoewel weersin teen belastingbetaling algemeen-menslik is, veral nog wanneer onbillikheid en misbruike aan die orde van die dag is, was belastingbetaling in die geval van die Jodedom des te pynliker omdat dit aan 'n vreemde owerheid moes geskied en belastingbetaling erkenning van die Romeinse gesag geïmpliseer het (vgl Mark 12:13-17 par). Daarbenewens was daar reeds vanaf die opstand onder Judas die Galileër religieuse motiewe aan die betaling van belasting gekoppel: Om belasting te betaal was om die soewereiniteit van 'n vreemde heerser in plaas van dié van God oor Israel te erken. Dit is dus 
baie moontlik dat die anti-Romeinse gevoelens veral in die vorm van 'n verset teen belastingbetaling onder die Jode te Rome begin posvat en via hulle gedreig het om op die plaaslike Christene oor te spring. Alhoewel Paulus nog nie voorheen in Rome werksaam was nie, blyk dit uit Romeine 14-15:13 dat hy nie heeltemal oningelig oor omstandighede onder die Romeinse Christene was nie. Ontstellende berigte oor gebeure en invloede wat hulle verhouding tot die Romeinse owerhede kon vertroebel, sou hom ook bereik het.

Afgesien van Borg se verklaring kry ons egter ook nog dié van Friedrich, Pöhlmann en Stuhlmacher. In 'n belangwekkende en goedberedeneerde ondersoek wys hulle op die bittere ongelukkigheid onder Rome se inwoners oor die verdrukkende belasting en tolstelsel tydens Nero se regering. Hulle kroongetuie is die Romeinse skrywer Tacitus ${ }^{25}$, wat soos volg skrywe:

"Toe die volk van Rome in dieselfde jaar $(58 \mathrm{nC})$ onder talle proteste beswaar teen die onbeskaamde optrede van die tollenaars (=publicani) gemaak het, het Nero gewonder of hy nie bevel moes gee dat alle tolgelde afgeskaf word nie. Die ouer raadgewers het egter, nie sonder om sy groothartigheid vooraf te roem nie, 'n oorhaastige besluit van sy kant gesmoor. Hulle het daarop gewys dat die ryk sou disintegreer indien die inkomste waardeur die staat aan die gang gehou word, sou verminder. Die opheffing van die tolgeld sou immers daartoe lei dat die afskaffing ook van direkte belastings geëis sou word. Die openlike hebsug van die tollenaars moes egter beperk word, sodat die las wat vir soveel jare sonder klag gedra is, nie deur nuwe verswaring in verbittering sou omslaan nie".

Dat die protesbeweging in Rome, wat ongetwyfeld ook die gevoelens in die provinsies weerspieel het, nie net oor indirekte belastings (=vectigalia) en die wanpraktyke wat daarmee gepaard gegaan het, gehandel het nie, maar ook, alhoewel in mindere mate, oor die direkte belastings (=tributa), blyk nie net uit die voorlaaste sin van die bostaande Tacitusaanhaling nie, maar ook uit die omvattendheid van die Neroniaanse hervorming wat op die protesaksie gevolg het. Indien die ontsteltenis oor die Romeinse belastingstelsel in die jaar $58 \mathrm{nC}$ op die spits gedryf is, moes daar alreeds in 55-56 nC, toe Romeine geskryf is, ongelukkigheid in Rome bestaan het, des te meer as die brief ' $n$ jaar of twee later gedateer moet word. Hierdie beswaardheid sou ook die Christene in Rome nie onaangetas gelaat het nie.

In verband met bogemelde aangeleentheid moet daarop gewys word dat Romeinse burgers sedert die Derde Masedoniese Oorlog (167 vC) 
normaalweg nie meer persoonlike belasting betaal het nie. Ook was die Italiaanse grondgebied van grondbelasting vrygestel. Die vraag ontstaan nou hoe daar dan van so 'n beswaardheid sprake kon wees.

Eerstens moet egter in gedagte gehou word dat Romeinse burgers wel by uitsonderlike geleenthede vir persoonlike belasting aangeslaan is, al was dit net 'n verbygaande maatreël. Ons het inligting dat dit op 'n stadium gedurende die eerste eeu vC gebeur het ${ }^{26}$. Ons weet beslis ook dat dit weer in die sestigerjare onder Nero plaasgevind het ${ }^{27}$. Iets hiervan kon ook reeds in die vyftigerjare in die lug gewees. Belangriker egter is die feit dat Romeinse burgers se vrystelling van een vorm van direkte belasting, naamlik grondbelasting, nie gegeld het vir besittings buite Italië nie ${ }^{28}$, en veral dat hulle, soos alle ander onderdane van die ryk, nog steeds aanspreeklik was vir die groot verskeidenheid indirekte belastings ${ }^{29}$ en ook die wanpraktyke van die publicani moes verduur. Vir die vryheidsliewende en trotse Romein was, soos uit die bronne blyk, die idee van belastingbetaling tradisioneel tot aanstoot ${ }^{30}$.

Tweedens moet die baie belangrike feit in gedagte gehou word dat Rome op hierdie stadium reeds 'n geweldige groot nie-Romeinse bevolking gehuisves het, waarvan die oorgrote meerderheid nie Romeinse burgerskap besit het nie en daarom vir alle belastings aanspreeklik was. Oor die algemeen word geskat dat die totale destydse bevolking van Rome sowat een miljoen was, waarvan minstens die helfte uit slawe of vrygelatenes bestaan het ${ }^{31}$. Wat die spesifieke aantal Jode in Rome betref, wissel moderne skattings aansienlik. Hulle wissel byvoorbeeld vir die jaar negentien $\mathrm{nC}$ tussen vyftien en vyftig duisend, waarvan sowat vier duisend weerbare mans die burgerreg besit het ${ }^{32}$. Tog het ' $n$ aansienlik groter getal hierdie burgerreg nie besit nie en moes derhalwe ook alle belastings betaal. Rondom die vyftigerjare toe Romeine geskryf is, moes die aantal Jode in Rome eerder hoër as laer gewees het. Die uitsettingsedik onder Klaudius het waarskynlik net die meer prominente Joodse figure getref ${ }^{33}$ en bowendien kon hulle na die dood van Klaudius in $54 \mathrm{nC}$ terugkeer. Wat die Christene in Rome betref, het ons ongelukkig min gegewens oor hierdie vroeë tydperk. Wayne Meeks is min of meer in die kol wees as hy sê dat die stedelike Christelike gemeenskappe van destyds 'n redelike spektrum van persone uit verskillende sosiale strata, uitgesonder die heel hoogstes en die heel laagstes, bevat het ${ }^{34}$. Tog het Lampe oortuigend aangetoon dat die Christengemeenskappe in Rome aanvanklik meerendeels tot die nederiger sosiale lae behoort het ${ }^{35}$. Dit is te betwyfel of meer as enkeles van hulle die Romeinse burgerskap besit het ${ }^{36}$. Afgesien van die Romeinse burgers self, sou die groot aantal ander nie-Romeinse burgers in Rome, waaronder ook 
talle Jode en Christene, goeie rede tot beswaardheid oor die belastings gehad het.

Albei bostaande standpunte ten opsigte van tydhistoriese probleme wat aanleiding kon gegee het tot die totstandkoming van Romeine 13:1-7 het goeie bestaansreg. Hulle hoef ook nie teenoor mekaar gestel te word soos meermale gebeur nie. Daar is soveel geldige oorwegings vir albei dat ons kan aanvaar dat hulle saamgewerk het om 'n negatiewe stemming teenoor die Romeinse owerheid en die betaling van belasting te skep. Hierdie situasie motiveer na alle waarskynlikheid die besondere aandag wat Paulus aan Christene se verpligtinge teenoor die staat gee en die breedvoerige wyse waarop hy sy standpunt motiveer.

Die verdere vraag is nou egter waarom dit vir Paulus so belangrik is dat die Christene te Rome hulle belasting betaal. Hy motiveer dit eerstens met die basiese stelling, wat sterk leun op tradisies in die Ou Testament en Vroegjodedom ${ }^{37}$, dat heersers deur God ingestel is en gehoorsaam moet word (13:1-4). Daarom moet die lesers hulle "ter wille van die gewete" onderwerp en nie net omdat hulle die owerheid se straf vrees nie. Ons kan egter ook aanvaar dat Paulus nog ander redes het. Dit gaan sekerlik vir hom daarom dat die Christelike huisgemeentes nie hulle eie voortbestaan deur dislojaliteit in gevaar moes stel nie ${ }^{38}$. Hulle was nog maar ' $n$ aantal klein en kwesbare groepies in ' $n$ groot en magtige omgewing. Verset of selfs net die skyn daarvan sou so 'n bedreiging na vore roep ${ }^{39}$. Hulle kon hulleself aan allerlei Romeinse strafmaatreëls soos byvoorbeeld verbanning uit Rome blootstel. Die beoefening van hulle huisbyeenkomste kon verbied word.

Ons moet in gedagte hou dat die Christene op hierdie stadium nog met die Jode geassosieer is. Reeds vanaf Cicero se tyd het daar by sekere groepe argwaan teen die Jode bestaan ${ }^{40}$. Vanweë hulle koppeling met die Jode was ook die Christene van vroeg af verdag. Hoe maklik hierdie bedreiging in ' $n$ daadwerklike krisis kon oorgaan, blyk uit die Christenvervolging van $64 \mathrm{nC}$. Aanvanklik is die Jode verdink, maar uiteindelik is die blaam op die Christene afgeskuif, iets wat des te makliker kon gebeur omdat hulle nog as 'n Joodse sekte beskou is. Alhoewel ons nie weet presies hoe goed Paulus oor omstandighede in Rome ingelig was nie, het hy die tekens tog reg gelees en besef hoe belangrik dit was dat die Christene hulle sou weerhou van enige verdagte optrede.

Daar was egter nog meer op die spel: Christenwees as sodanig, die evangelie self kon in diskrediet kom. Ons weet uit ander NuweTestamentiese gedeeltes hoe Christene telkemale om missionêre redes gemaan word om hierteen te waak en in alle opsigte 'n voorbeeld deur 
hulle optrede te stel ${ }^{41}$. Hulle moet dus agteroor buig en eerder onreg verduur as om die goeie naam van Christus en die evangelie in gedrang te bring $^{42}$. Uit die latere geskiedenis van die Christene in die Romeinse Ryk weet ons dat hierdie gevaar nie denkbeeldig was nie. Benko het breedvoerig aangetoon aan watter argwaan, wanvoorstellings en verdagmaking Christene blootgestel was ${ }^{43}$.

Indien die bostaande argumentasie korrek is, verklaar dit waarom Paulus dit as dringend nodig sou beskou het om Romeine 13:1-7 te skrywe. Ons kan egter nou ook insien dat hierdie gedeelte in werklikheid nog sterker in sy konteks inpas as wat ons vroeër gemeen het: Dit word 'n konkretisering, 'n praktiese voorbeeld van die soort etiese gedrag wat in die voorafgaande gedeelte in meer algemene terme voorgeskryf word. In Romeine 12:1-2 word die Christene opgeroep tot 'n lewenstyl wat anders is as die van die "sondige wêreld" rondom hulle. Dit doen hulle inderdaad wanneer hulle hulle nie teen die owerhede verset nie en hulle belasting op voorbeeldige wyse betaal. Heiligenthal ${ }^{44}$ het die soort optrede wat in Romeine 13:1-7 van die Christene gevra word as "konformerende etiek" beskryf. Dit is egter ' $n$ ongelukkige karakterisering. Wat van die Christene gevra word, is nie konformerende gedrag nie, maar juis onderskeidende gedrag. Wanneer die hele omgewing brom en mor oor belastings, moet hulle hulle juis onderskei deur hulle andersheid. Hulle moet juis, anders as hulle omgewing, doen wat die wil van God is en wat in sy oog "goed" is (v 2 vgl 13:3) deur die owerhede wat juis Hy daargestel het, te gehoorsaam. Wanneer hulle positief teenoor die staat se belastingbeamptes en die publicani optree wat hulle sleg behandel en miskien selfs "vervolg" (v 14), is hulle konkreet besig om nie "kwaad met kwaad" te vergeld nie ( $\mathrm{v} 17$ ), om "in vrede" met alle mense te lewe (v 18), om nie terug te reageer nie, maar die oordeel aan die Here oor te laat (v 19) en om "die kwaad deur die goeie" te oorwin ( $v$ 21). McDonald ${ }^{45}$, wat hierdie aspek goed raakgesien het, verklaar tereg dat Paulus die gelowiges wil genees van die $\dot{\alpha} \nu \tau i-$ sindroom ( $\mathrm{vgl}$ v 17) wat so tipies van wêreldse mense is. Ook 13:8a kom egter nou in ' $n$ nuwe lig te staan. Om aan niemand iets verskuldig te wees nie, sluit nou in dat ' $n$ mens ook nie aan die belastinggaarder geld verskuldig moet bly nie. Interessant genoeg het De Kruijf in hierdie verband gemeen dat Romeine 13:8a nog as deel van die voorafgaande uitvoerings oor die Christen en die staat beskou moet word ${ }^{46}$. Vers $8 \mathrm{a}$ vorm egter so ' $n$ integrale deel van wat volg, dat dit foutief sou wees. Dit vorm in werklikheid 'n oorgang, soos ons so dikwels in die Nuwe Testament kry, waarin die voorafgaande in die vorm van 'n gevolgtrekking nog naklink, maar wat reeds sterker by die opdrag tot die naasteliefde hoort. 
Ons kan dus die gevolgtrekking nie vermy dat Paulus Romeine 13:1-7 van die begin af as deel van sy paranese gekonsipieer het nie, met ander woorde dat dit ook nie ' $n$ interpolasie is wat hy agterna ingewerk het nie.

Uit die voorafgaande blyk hoe kennis van die sosio-historiese konteks waarbinne Romeine 13:1-7 geskrywe is, nie net die ontstaan en bestaan van hierdie gedeelte kan verhelder nie, maar ook kan verduidelik hoe integraal dit in werklikheid in sy konteks inpas. Vervolgens gaan ons, sonder om enigsins breedvoerig op die eksegese van Romeine 13:1-7 in te gaan ${ }^{47}$, nog kortliks kyk na enkele aspekte waarin agtergrondkennis ons verstaan van die fyner detail van hierdie passasie verryk.

Strobel ${ }^{48}$, aangevul deur Van Unnik ${ }^{49}$, het aangetoon hoe Romeine 13:1-7 op veelvuldige wyse die staatsregtelike en administratiewe taal van die destydse Grieks-Romeinse wêreld reflekteer ${ }^{50}$. So dui die

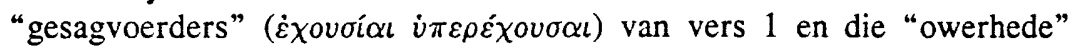

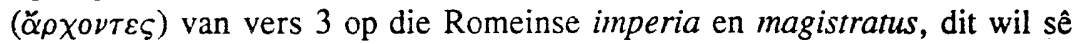
die hordes amptenare wat die Romeinse staatsapparaat oor die ganse Romeinse ryk verteenwoordig het ${ }^{51}$.

Om goeie optrede te prys en die kwaad te straf (vv 3-4) is reeds sedert Xenophon as deel van die tipiese pligte van 'n regeerder beskou ${ }^{52}$. 'n Illustrasie hiervan was die gebruik van die Romeinse owerheid om aanprysingsbriewe te rig aan stede en ampsdraers wat hulleself deur hulle welwillende optrede teenoor Rome onderskei het ${ }^{53}$. Strobel ${ }^{54}$ bied hiervoor 'n lang lys van voorbeelde aan. Onder hierdie lofskrywes is daar briewe aan ampsdraers, aan die plaaslike owerhede en inwoners van 'n stad, aan mans en aan vrouens.

Die benoeming van beamptes, ook finansiële beamptes, as "dienaars" ( $\lambda \varepsilon \iota \tau o u ́ \rho \gamma o l$ ) (vgl Rom 13:6) was in die destydse GrieksRomeinse wêreld heel algemeen ${ }^{55}$, alhoewel die byvoeging "van God" op die Joods-Ou-Testamentiese bodem van Paulus se teologiese denke teruggevoer moet word56. Paulus se stelling dat die owerheid "nie verniet

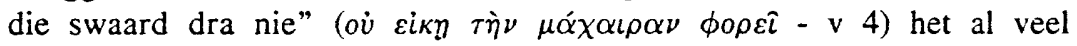
bespreking uitgelok ${ }^{57}$. Ten spyte van die feit dat tot dusver geen presiese parallel vir Paulus se formulering gevind kon word nie, is die mees aanvaarbare standpunt tog dat hy hier aan die Romeinse ius gladii dink, wat hier dui op die bevoegdheid van Romeinse beamptes om straf, in besonder ook die doodstraf, te voltrek.

Met vers 13 bereik Paulus se argument die eintlike spits waarop hy afstuur ${ }^{58}$. Die terme $\phi o ́ \rho \circ \varsigma$ en $\tau \varepsilon \lambda o \varsigma$ verwys onderskeidelik na die hoofvorms van verpligte destydse staatsinvordering. Eersgenoemde was die direkte belasting (Latyn: tributum) en laasgenoemde die indirekte 
(Latyn: vectigalia). Die direkte belasting het bestaan uit grondbelasting (tributum soli) en kopbelasting (tributum capitis) en is gewoonlik nie deur Romeinse burgers betaal nie ${ }^{59}$. Slegs nie-Romeinse burgers wat spesiale kwytskelding ontvang het, was hiervan vrygestel. In die geval van mans is dit gewoonlik vanaf veertien tot vyf en sestig jaar, in die geval van vrouens vanaf twaalf tot vyf en sestig betaalbaar. Ook slawe was vir hierdie belasting aanspreeklik. Hoe groot die direkte belasting was, weet ons nie presies nie. Ons weet wel dat die periodieke sensusgeleenthede as basis vir die belastingaanslag gedien het. In Sirië en Silisië is hierdie direkte belasting bereken teen een persent van hulle finansiële evaluasie tydens die voorafgaande sensus. In Palestina kon hierdie belasting minstens een denarius per persoon per jaar beloop het ${ }^{60}$. Ook weet ons dat die belastingdruk in die jaar $17 \mathrm{nC}$ in Sirië en Judea so swaar was dat 'n gesamentlike deputasie by keiser Tiberius vir belastingverligting gaan pleit het ${ }^{61}$.

Die groot verskeidenheid indirekte belastings is onder meer gehef op die inbring van ware by hawens en grense (doeanebelasting = portoria), op produkte soos sout waarop die staat monopolieë gehad het, op die verkoop en vrylating van slawe, verkoopsbelasting (vir Italië egter afgeskaf deur Kaligula), boedelbelasting, mynbelasting ensomeer ${ }^{62}$. Die heffing op die verkoop van slawe was vier persent en op hulle vrylating vyf persent van hulle waarde. Die verdere probleem was dat hierdie indirekte belastings telkens deur die vindingrykheid van Romeinse of plaaslike owerhede vermeerder is. Die sogenaamde tollenaars of publicani het vir hierdie indirekte belastings getender, maar het meermale ook gehelp met die invordering van direkte belasting. Hulle was in gildes georganiseer en het nie geskroom om hulle magsposisie tot hulle eie voordeel te misbruik nie $^{63}$. Hulle het vir die indirekte belastings getender en alles wat hulle bo die getenderde bedrag kon in, kon na hulle eie beursies toe gaan. Geen wonder dat iemand soos Saggeus nogal heelwat gehad het om teenoor sy medemens reg te maak nie (Luk 19:7-8). As al die bostaande oorwegings in ag geneem word, kan ons begryp dat die gewone man, veral die nieRomein, die belastinglas sterk negatief moes beleef het. Hiervan is die bostaande aanhaling uit Tacitus 'n klinkende bewys.

In die voorafgaande het ons sekere aspekte van die positiewe gebruik van agtergrondinligting uitgelig. In die geval van Romeine 13:1-7 kry ons egter ook 'n goeie voorbeeld van hoe agtergrondkennis nie behoort gebruik te word nie. Paulus se optimistiese siening oor die staat in Romeine 13:1 word soms toegeskryf aan sy eie positiewe belewenis van die Romeinse owerheid $^{64}$. Hy skryf sy Romeinebrief gedurende die goeie jare van die 
sogenaamde quinqennium Neronis, die eerste vyf jaar van Nero se regering (54-59 $\mathrm{nC}$ ), toe Burrus en Seneka nog sy raadgewers was en allerlei tekens van hervorming in die staatshuishouding en regspleging te bespeur was. Goeie aanstellings is gemaak. Die provinsies is oor die algemeen goed regeer. Daar is nie geskroom om hooggeplaaste amptenare weens korrupsie voor die hof te bring nie. Dit was inderdaad die gelukkigste tyd in die Romeinse ryk sedert die dood van Augustus ${ }^{65}$. Van die moontlikheid van 'n komende Christenvervolging soos dié in Julie $64 \mathrm{nC}$ sou niemand op hierdie stadium kon droom nie. Nero sou eers later 'n moedermoordenaar en Christenvervolger word ${ }^{66}$. Bowendien was Paulus self afkomstig van Tarsus, 'n stad wat op velerlei wyse deur die Romeine begunstig was. Op sy reise het hy die voordele van die pax romana ondervind. Telkens kon hy beleef hoe hy die Romeinse sin vir reg en orde ' $n$ temperende invloed op massageweld en onreg uitoefen (Hand 19:35-40; 21:30-36; 22; 23:12-32). As Romeinse burger was hy selfs bevoorreg om hom, in die lig van moontlike verontregting deur 'n plaaslike bewindhebber, op die keiser te beroep (Hand 25:11-12).

Teenoor hierdie positiewe gesigspunte sou ingebring kon word dat Paulus ook van talle misstappe deur Romeinse maghebbers bewus moes gewees het. Hy sou beslis geweet het van talle gevalle van onreg en wreedheid op plaaslike vlak, van die bloedspoor van Pilatus, van die eksentrieke optredes van Tiberius, van die grootheidswaansin van Kaligula en die Jodeverdrywing onder Tiberius. Self moes hy, ten spyte van sy Romeinse burgerskap, drie keer onregmatige lyfstraf onder Romeinse magistrate verduur ( 2 Kor $11: 25)^{67}$. Ten spyte van hierdie negatiewe gesigspunte sou die talle positiewe aspekte van die pax romana, van die Romeinse staatsideaal en sekerlik ook van Paulus se oorwegend positiewe belewenis van die Romeinse staat, in besonder van die eerste jare van Nero se bewind, nietemin meegebring het dat sy geheelvisie op die Romeinse staatspraktyk positief sou bly. Paulus sou gemelde negatiewe aspekte eerder beskou het as insidentele uitsonderings ten opsigte van 'n oorwegend positiewe staatsbestel ${ }^{68}$.

Om nou op bogenoemde standpunt terug te kom: Moet Paulus se ongekwalifiseerd positiewe evaluering van die staat nie inderdaad gelees word vanuit ons agtergrondkennis van die quinquennium Neronis en sy positiewe geheelvisie op die Romeinse staatsbestel nie? Met ander woorde, moet ons nie inderdaad aanvaar dat Paulus veel negatiewer oor die Romeinse staat sou geskryf het indien hy sy Romeinebrief na die Christenvervolgings van Julie $64 \mathrm{nC}$ geskryf het nie? Hierdie standpunt sou 'n welkome uitvlug bied vir almal wat Romeine 13:1-7 se positiewe 
staatsbeskouing as 'n probleem ervaar. Tog sou hierdie soort gebruik van agtergrondkennis ontoelaatbaar wees, omdat dit teen die grein van die teks self ingaan. Romeine 13:1-7 se formulering is duidelik nie afgestem op 'n partikuliere situasie nie ${ }^{69}$. Dit is prinsipieel veralgemenend; dit stel hoe die staat vanuit Christelike standpunt behoort te wees: 'n dienaar van God wat deur Hom vir die welwese van sy onderdane ingestel is en as sodanig deur laasgenoemde gerespekteer en gehoorsaam behoort te word. Wat ons vanuit ons agtergrondkennis egter wel kan sê, is dat Paulus sy prinsipiële standpunt hier sonder kwalifiserings en voorbehoude kan aanbied as gevolg van die oorheersend positiewe konteks waaruit hy skrywe. Met ander woorde ons kan aanvaar dat hy na 64 nie sy prinsipiële standpunt sou verander het nie, maar wel meer genuanseerd sou geformuleer het. Daar is immers in Romeine 13:1-7 self genoeg ingeboude voorbehoude teenoor 'n staat wat nie meer werklik as dienaar van God optree nie, wat nie meer ten goede van sy onderdane regeer nie, wat Christene sou probeer dwing om nie meer volgens nie, maar teen hulle gewete te handel.

Openbaring 13 trek die konsekwensies van so 'n verworde staatsbestel. So 'n staat is nie meer 'n dienskneg van God nie, maar van Satan. Hy regeer nie meer sy onderdane ten goede nie, maar ten kwade. Die Christene mag hom nie meer dien ter wille van die gewete nie, maar moet ter wille van die gewete hom juis ongehoorsaam wees. Soos in Romeine moet hulle dit egter vanselfsprekend nog steeds doen op 'n wyse wat pas by die voorbeeldige lewenstyl van mense wat aan Christus behoort.

\section{NOTAS:}

1 Vergelyk in hierdie verband die uitstekende artikel van J M G Barclay, "'Mirror-reading' a polemical letter: Galatians as a test case", JSNT 31(1987), 73-93.

2 Kyk veral E P Sanders, Paul and Palestinian Judaism, London ${ }^{2} 1981$.

3 W Wilckens, Römer 13,1-7, in: Rechtfertigung als Freiheit. Paulusstudien, Neukirchen 1974, 215.

4 T C de Kruijf, "The literary unity of Romans 12:16-13:8a. A network of inclusions", Bijdragen 48 (1987), 319-326.

5 O Michel, Der Brief an die Römer (KEK IV), Göttingen 14.151978, 395-397.

6 H Ridderbos, Aan de Romeinen (Commentaar op het Nieuwe Testament), Kampen 1959, 287. 
7 E Barnikol, Römer 13: Der nichtpaulinische Ursprung der absoluten Obrigkeitsbejahung von Römer 13:1-7 (TU 77), Berlin 1961, 65-133.

8 J Kallas, “Romans XIII.1-7: An interpolation”, NTS 11 (1964-1965), 366.

9 J C O'Neill, Paul's Letter to the Romans, Harmondsworth 1975, 207.

10 W Schmithals, “Der Römerbrief als historisches Problem”, StNT 9 (1975), 185187; vergelyk $191 \mathrm{vv}, 211$.

11 W Munro, Authority in Paul and Peter (SNTSMS 45), Cambridge 1983, 3.

12 J Friedrich, W Pöhlmann \& P Stuhlmacher, “Zur historischen Situation und Intention von Röm 13,1-7”, ZThK 73 (1976), 147-148.

13 Wilckens, $a w, 214$.

14 J Friedrich, W Pöhlmann \& P Stuhlmacher, $a w, 147$.

15 Wilckens, $a w, 215$.

16 Friedrich, Pöhlmann \& Stuhlmacher, $a w, 148-149$.

17 F F Bruce, "Paul and 'the powers that be'", BJRL 66 (1983-1984), 81.

18 Vergelyk Friedrich, Pöhlmann \& Stuhlmacher, $a w, 149$.

19 J D G Dunn, Romans 9-16 (WBC 38), Dallas 1988, 758.

20 Friedrich, Pöhlmann \& Stuhlmacher, $a w, 153$. So ook C E B Cranfield, Romans II (ICC), Edinburgh 1979, 652-653.

21 E Käsemann, "Grundsätzliches zur Interpretation von Römer 13”, in: Exegetische Versuche und Besinnungen II, Göttingen 1964, 216-218; An die Römer (HNT 8a), Tübingen ${ }^{3} 1974,338$.

22 G Strecker, Handlungsorientierter Glaube. Vorstudien zu einer Ethik des Neuen Testaments, Berlin 1972, 27.

23 H J Leon, The Jews of Rome, Philadelphia 1960, 135-136.

24 M Hengel, Die Zeloten. Untersuchungen zür jüdischen Freiheitsbewegung in der Zeit von Herodes 1. bis 70 n. Chr., Leiden-Köln 21876, 139-145.

25 Tacitus Annales 13:50-51, vergelyk ook Suetonius, Nero 10.

26 Kyk O Michel, $a w, 403$. 
27 Suetonius: Nero 44; Tacitus: Annales 15:45. Vergelyk W Schwahn, Tributum und tributus, Paulys Real-Encyclopädie der classischen Altertumswissenschaft VII, Waldsee 1948, kol 53.

28 O Michel, $a w, 403$ nota 34.

29 'n Breër uiteensetting van die breë spektrum wat hierdie belastings gedek het, volg later.

30 G H Stevenson \& F G B Millar, "Vectigal", Oxford Classical Dictionary, Oxford ${ }^{2} 1970,1110$.

31 Kyk R P Duncan-Jones, “Population (Roman)”, Oxford Classical Dictionary, Oxford 21970, 863-864; R P Saller, "Roman Empire", Oxford Companion to the Bible, New-York-Oxford 1993, 658.

32 P Lampe, Die stadtrömischen Christen in den ersten beiden Jahrhunderten (WUNT 2.18), Tübingen $21989,66-67$.

33 Lampe, $a w, 4-8$.

34 W Meeks, The first urban Christians. The social world of the apostle Paul, New Haven-London 1983, 51-73.

35 Lampe, $a w, 65-123$.

36 Lampe se afleiding op grond van die regsprosesse wat die marteldood van Christene in die jaar $64 \mathrm{nC}$ voorafgegaan het dat 'n "groot aantal" Christene nie Romeinse burgerskap besit het nie, is waarskynlik nog heeltemal te ruim gestel.

37 Vergelyk die uiteensetting by Friedrich, Pöhlmann en Stuhlmacher, $a w, 145$ 146.

38 Friedrich, Pöhlmann \& Stuhlmacher, $a w, 159 ; \mathrm{R}$ Heiligenthai, "Strategien konformer Ethik im Neuen Testament am Beispiel von Röm 13.1-7”, NTS 29 (1983), 55-61; Dunn, $a w, 769-774$; J Botha, "Social values in the rhetoric of Pauline paranetic literature", Neotestamentica 28 (1994), 125; J L P Wolmarans, "The rhetoric and logic of Romans 13:1-7", Ekklesiastikos Pharos 76 (1994), 191.

39 Beklemtoon deur $\mathrm{H}$ Conzelmann \& A Lindemann, Arbeitsbuch zum Neuen Testament (UTB 52), Tübingen 1976, 419; Friedrich, Pöhlmann \& Stuhlmacher, $a w, 161-163$; Dunn, $a w, 770-772$.

40 Kyk M Stern, "The Jews in Greek and Latin literature", in: S Safrai \& M Stern (eds), The Jewish people in the first century II (CRINT I), Assen-Amsterdam 
1976, 1144-1159; S Benko, Pagan Rome and the early Christians, Bloomington-Indianapolis 1986, 17-20. Vir anti-judaissme teen die Jode reeds op 'n vroeêr stadium, kyk E Gabba, The growth of anti-Judaism or the Greek attitude towards Jews, Cambridge History of Judaism 2, London-New York 1989, 614 656. Die poging van J G Gager, "Judaism as seen by outsiders", in: R A Kraft \& G W E Nickelsburg (eds), Early Judaism and its modern interpreters, Atlanta 1986, 99-116 om hierdie anti-Judaistiese houding te minimaliseer is nie cortuigend nie.

41 Kyk verder by W C van Unnik, "Die Rücksicht auf die Reaktion der NichtChristen als Motiv in der altchristlichen Paränese”, in: W Eltester (Hrsg), Judentum - Urchristentum - Kirche. Festschrift für Joachim Jeremias, Berlin 1964, 221-234; D van Schwigchem, Het missionair karakter van de christelike gemeente volgens de brieven van Paulus en Petrus, Kampen 1955.

42 Vir hierdie missionêre oorweging vergelyk ook Friedrich, Pöhlmann \& Stuhlmacher, $a w, 161$.

43 Benko, $a w$. Hy wy sy hele boek aan hierdie aangeleentheid.

$44 \quad \mathrm{R}$ Heiligenthal, $a w, 55-61$.

45 J I H McDonald, "Romans 13:1-7: a test-case for New Testament interpretation", NTS 35 (1989), 546-547.

De Kruijf, $a w$.

47 Van die publikasies oor Romeine 13:1-7 wat in die jongste tyd op SuidAfrikaanse bodem verskyn het, noem ek hier die volgende: B C Lategan, "Reception theory and practice in reading Romans 13", in: P J Hartin \& J H Petzer, Text and interpretation. New approaches in the criticism of the New Testament (NTTS XV), Leiden-New York 1991, 145-169; J Botha, Reading Romans 13. Aspects of the ethics of interpretation in a controversial text (Doctoral dissertation: University of Stellenbosch), Stellenbosch 1991; J Botha, "Social values in the rhetoric of Pauline paranetic literature", Neotestamentica 28 (1994), 109-126; Wolmarans, $a w, 187-199$; F Hale, "Romans 13:1-7 in South African Baptist Social ethics", South African Baptist Journal of Theology (1992), 66-83. Afgesien van Wolmarans wat enigsins breër aandag aan die tydhistoriese situasie gee, lê die fokus van hierdie publikasies egter op ander aspekte.

48 A Strobel, “Zum Verständnis von Rm 13”, ZNW 47 (1956), 67-95; A Strobel, Furcht, wem Furcht gebührt. Zum profangriechischen Hintergrund von Romeine 13,7, ZNW 55 (1964), 58-62.

49 W C van Unnik, "Lob und Strafe durch die Obrigkeit. Hellenistisches zu Röm 13,3-4”, in: E E Ellis \& E Grässer (Hrsg), Jesus und Paulus. Festschrift für W G Kümmel zun 70. Geburtstag, Göttingen 1975, 334-343. 
50 Kyk ook Friedrich, Pöhlmann \& Stuhlmacher, $a w, 135-145$.

51 Strobel, “Zum Verständnis von Rm 13”, 79.

52. Van Unnik, $a w, 336$.

53 Strobel, "Zum Verstāndnis von Rm 13", 79.

54 Strobel, ibidem, 81-84.

55 Strobel, ibidem, 86-87.

56 Vergelyk veral Friedrich, Pöhlmann \& Stuhlmacher, $a w, 146$.

57 Kyk die bespreking by Friedrich, Pöhlmann \& Stuhlmacher, $a$ w, 140-144.

58 Dunn, $a w, 766$, noem vers 7 tereg die klimaks van hierdie passasie.

59 Vergelyk oor hierdie belastings W Schwan, $a w$, kol.1-78; E Schürer, The history of the Jewish people in the age of Jesus Christ (175 B.C. - A.D. 135) (Bygewerkte Engelse uitgawe onder redaksie van G Vermes \& F Millar van sy Geschichte des Jüdischen Volkes im Zeitalter Jesu Christi, Leipzig ${ }^{3 / 4} 1901-1909$ ) I, Edinburgh 1973, 372-376,415-427; E Badian, "Tribute and taxation", Oxford Companion to the Bible, 781-782; F G B Millar, "Tributum", Oxford Classical Dictionary, 1093; Michel, $a w, 403$ en aldaar voetnoot 34.

$60 \quad$ Badian, $a w, 782$.

$61 \quad$ Tacitus, Annales 2:42.

62 T Pekáry, Vectigal, Der kleine Pauly. Lexikon der Antike V, 1150; Stevenson \& Millar, Vectical, Oxford Classical Dictionary, Oxford ${ }^{21970}, 1110$.

63 Kyk in hierdie verband veral B Reicke, Neutestamentliche Zeitgeschichte, Berlin 1964, 103-104.

64 In verband met hierdie posisie kan W Sanday \& A C Headlam, The Epistle to the Romans (ICC), Edinburgh 51914, 371 geraadpleeg word; ook H Ridderbos, Aan de Romeinen, Kampen 1959, 289-290; A A Boesak, "What belongs to Caesar? Once again Romans 13”, in: Boesak \& Villa-Vicencio (eds), $A$ call for an end to unjust rule, Philadelphia 1986, 144-145.

65 So tereg Sanday \& Headlam, $a w$, xiv. Hierdie skrywers gee ook 'n uitvoerige beskrywing van ander positiewe aspekte van die Romeinse bewind gedurende die quinqennium: vergelyk $a w$, xiv-xvi. 
66 T Zahn, Der Brief des Paulus an die Römer, Leipzig 1,2 1910, 558.

67 Kyk die bespreking by R P Martin, 2 Corinthians (WBC 40), Waco 1986, 377.

68 So reeds Zahn, $a w, 558$.

69 So onder andere ook Sanday \& Headlam, $a w, 371$; Ridderbos, $a w, 289-290$; Boesak, $a w, 144-145$. 